\title{
QUALITY IMPROVEMENT OF DISQUALIFIED TIGER PRAWN (PENAEUS MONODON FAB.) BROODSTOCK USING DOPAMINE
}

\author{
ETTY RIANI ${ }^{1}$, MOZES TOELIHERE ${ }^{\dagger 2}$, ICHSAN EFFENDIE ${ }^{1}$, \\ TUTI L YUSUF ${ }^{2}$ AND SRIHADI AGUNGPRIYONO ${ }^{3}$ \\ ${ }^{1}$ Department of Aquatic Resources Management, Faculty of Fisheries and Marine Sciences, \\ Bogor Agricultural University, Bogor 16680, Indonesia \\ ${ }^{2}$ Department of Biology Reproduction, Faculty of Veterinary Science, \\ Bogor Agricultural University, Bogor 16680, Indonesia \\ ${ }^{3}$ Department of Anatomy and Histology, Faculty of Veterinary Science, \\ Bogor Agricultural University, Bogor 16680, Indonesia
}

\begin{abstract}
Disqualified tiger prawn broodstock has undergone ablation after two breeding periods, which causes high production cost, pollution of environment and difficulties in providing the broodstock continuously with enough quantity at an exact time. The purpose of this study was to find the proper dosage of dopamine to improve the quality for breeding of the disqualified tiger prawn, because dopamine inhibits maturation, so there will be enough time for maturation and improvement of the eggs quality.

This experiment used 15 pairs of the twice breeding tiger prawn, which was collected from Perigi (Central Java). The samples were treated with different dosages of dopamine (dosage $10^{-9}$, $10^{-8}, 10^{-7}, 10^{-6} \mathrm{moll}$ and control/injected with aquabidest). The parameters identified in this experiment were duration (days) for eggs maturation, fecundity, fertilizing rate, hatching rate, egg diameter and phototaxis response of the nauplii.

The research concluded that the average duration for eggs maturation on the broodstock that were injected with dopamine, dosage $10^{-9}, 10^{-8}, 10^{-7}, 10^{-6}$ moll and control, were $14,12,4,2,5$ days, respectively. Fecundities were 561.489, 503.000, 384.205, 230.850 and 150.034. Fertilizing rates were $89.8 \%, 82.1 \%, 56.0 \%, 46.3 \%$, and $23.2 \%$. Hatching rates were $79.53 \%, 72.53 \%$, $47.75 \%, 12.27 \%$, and $36.6 \%$. Diameters were $0.29 ; 0.29 ; 0.29 ; 0.27$; and $0.27 \mathrm{~mm}$. The nauplii produced by injecting broodstock with dopamine dosages of $10^{-9}, 10^{-8}, 10^{-7}$, have positive phototaxis response, while for dosage $10^{-6}$ and control the responses were weak.
\end{abstract}

Keywords: Penaeus monodon, dopamine, dosage, duration maturation, fecundity, fertilizing rate, hatching rate, egg diameter, nauplii

*Corresponding author: etty_riani_harsono@yahoo.com 


\section{INTRODUCTION}

The tiger prawn (Penaeus monodon $\mathrm{Fab}$.) ranks the first among the agricultural export commodities of which the demand from domestic as well as from abroad is very high; and this prawn is a profitable product. So people are interested to invest in this commodity.

Although in the last 20 years the research of the prawn culture technology has developed but there are still many problems. For example, in hatchery there are always problems of broodstocks. The broodstock for the hatchery is caught from the open sea in which there were ablations. The natural broodstocks in hatchery were used because they are identified as the best quality. Serious problems are difficulty in providing mature broodstock at an exact time, obtaining the desired quality, high price, and continuous buying of the stock by the hatchery. After two times breeding, the broodstocks become disqualified, so that production cost will be high, moreover it will disturb the stability of the ecosystem (sea ecosystem), and after all, difficulties in providing the broodstock continuously.

After two times breeding, broodstocks are disqualified because they have lower fecundity and the eggs are bad. A research to improve the disqualified broodstock is needed. According to the fish and mammal research, dopamine can inhibit gonadothropine hormone production. In the red swamp crayfish, Procambarus clarkii, dopamine inhibits maturation of the testis (Sarojini, Nagabhusahanam \& Fingerman 1995). This hormone may be used to inhibit Gonadothropine Stimulating Hormone production in the ablation broodstock and the period of eggs maturation can last longer. In addition, the quality of the disqualified broodstocks is similar with those of the nature.

The purpose of this experiment is to find the proper dosage of dopamine which will give good quality for breeding of the disqualified tiger prawn.

\section{MATERIALS AND METHODS}

The experiments were conducted from February to April 2000 at BADP hatchery, Tasikharjo, Tuban, East Java. This experiment used 15 pairs after two times breeding of tiger prawn (disqualified), which is taken from Perigi (Central Java). The hormone used in this experiment is dopamine. The other material is chemical for water analysis and water treatment.

The broodstocks were kept in the circle water tank (total volume 10.000 liter). This tank is filled with 6000 liter of sea water. During this experiment the broodstocks were fed with chopped up fresh crab and fresh squid and also fresh sea worm. The feeding time is at 7.00,11.00, 15.00, 19.00, and 23.00 (adlibitum). After twice breeding in the evening, the following day in the morning at 07.00 the prawn is injected at 07.00 (Riani, Hitam \& Eidman 1995b) with different dosages i.e. $10^{-9}, 10^{-8}, 10^{-7}, 10^{-6}$ moll of dopamine and control. Each treatment is repeated three times. The parameters identified in this experiment are duration (days) for eggs maturation, fecundity, fertilizing rate, hatching rate, eggs diameter, and phototaxis responsive of the nauplii. 


\section{RESULTS AND DISCUSSIONS}

The average duration of egg maturation on the broodstocks injected with dopamine $10^{-9}, 10^{-8}, 10^{-7}, 10^{-6}$ moll and control were $14,12,4,2,5$ days, respectively (Table 1).

Table 1. The duration of egg maturation on the disqualified tiger prawn broodstock injected with Dopamine.

\begin{tabular}{cccccc}
\hline \multirow{3}{*}{ Broodstock } & \multicolumn{5}{c}{ Duration of eggs maturation (days) } \\
\cline { 2 - 6 } & $10^{-9}$ & $10^{-8}$ & $10^{-7}$ & $10^{-6}$ & control \\
\cline { 2 - 6 } & 14 & 11 & 5 & 2 & 8 \\
2 & 16 & 12 & 4 & 2 & 5 \\
3 & 13 & 13 & 4 & 2 & 3 \\
Average & 14.3 & 11.7 & 4.3 & 2 & 5.3 \\
\hline
\end{tabular}

The dosage of $10^{-9}$ moll dopamine delayed the duration of eggs maturation of the disqualified tiger prawn. This duration is longer than normal ablation, i.e. 3 - 5 days (Primavera 1983). Although at the dosage of $10^{-6}$ moll the duration is the shortest, in general high dosage of the hormone can cause rebound phenomenon.

The fecundity average of the broodstocks injected with dopamine of dosage $10^{-9}$, $10^{-8}, 10^{-7}, 10^{-6}$ moll and control were $561.489 ; 503.000 ; 384.205 ; 230.850$; and 150.034, respectively (Table 2).

Table 2. Fecundity of the disqualified tiger prawn broodstocks injected with dopamine

\begin{tabular}{cccccc}
\hline \multirow{2}{*}{ Broodstock } & \multicolumn{5}{c}{ Fecundity } \\
\cline { 2 - 5 } & \multicolumn{5}{c}{ Dosage of dopamine (moll) } \\
\cline { 2 - 5 } & $10^{-9}$ & $10^{-8}$ & $10^{-7}$ & $10^{-6}$ & Control \\
\hline 1 & 498.674 & 476.889 & 404.871 & 301.102 & 211.099 \\
2 & 649.473 & 521.403 & 337.456 & 219.847 & 139.248 \\
3 & 536.320 & 510.708 & 542.327 & 171.601 & 99.755 \\
Average & 561.489 & 503.000 & 384.205 & 230.850 & 150.034 \\
\hline
\end{tabular}

The fecundity, fertilizing rate and hatching rate of the broodstock injected with dopamine $10^{-9}$ moll showed the highest. According to Tseng (1987), the average of fecundity the ablation broodstock is 300000 . The quality of the disqualified broodstock injected with dopamine dosage $10^{-9}, 10^{-8}$, and $10^{-7}$ moll was higher than the normal ablation broodstock. In this experiment, generally the broodstock was injected with dopamine at dosages of $10^{-9}, 10^{-8}, 10^{-7}$ moll resulting to total spawning, while the dosage of $10^{-6}$ and control caused partial spawning. It was caused by the dopamine dosage of $10^{-9}$, and $10^{-8}$ moll giving a longer time for vitellogenesis so that quality and quantity of the eggs maturation were higher than others. Thus, the fertilizing rate and the hatching rate are higher too (Table 3 and Table 4). 
Table 3. Fertilizing rate of the disqualified tiger prawn broodstock injected with dopamine (\%)

\begin{tabular}{cccccc}
\hline \multirow{2}{*}{ Broodstock } & \multicolumn{5}{c}{ Fertilizing rate (\%) } \\
\cline { 2 - 5 } & \multicolumn{5}{c}{ Dosage of dopamine (moll) } \\
\cline { 2 - 5 } & $10^{-9}$ & $10^{-8}$ & 50.9 & $10^{-7}$ & Control \\
\hline 1 & 95.3 & 90.4 & 69.4 & 39.5 & 22.9 \\
2 & 82.3 & 80.9 & 47.7 & 59.3 & 29.1 \\
Average & 91.8 & 75.0 & 56.0 & 46.3 & 23.2 \\
\hline
\end{tabular}

Table 4. Hatching rate of the disqualified tiger prawn broodstock injected with dopamine (\%)

\begin{tabular}{cccccc}
\hline \multirow{2}{*}{ Broodstock } & \multicolumn{5}{c}{ Hatching rate (\%) } \\
\cline { 2 - 5 } & \multicolumn{5}{c}{ Dosage of dopamine (moll) } \\
\cline { 2 - 5 } & $10^{-9}$ & $10^{-8}$ & $10^{-7}$ & $10^{-6}$ & Control \\
\hline 1 & 80.21 & 71.40 & 49.07 & 16.52 & 29.58 \\
2 & 76.35 & 73.98 & 44.0 & 0 & 40.24 \\
3 & 82.03 & 72.21 & 50.18 & 20.29 & 39.98 \\
Average & 79.53 & 72.53 & 47.75 & 12.27 & 36.60 \\
\hline
\end{tabular}

The nauplii resulted from broodstock injected with dopamine $10^{-9}, 10^{-8}, 10^{-7}$ moll had a positive phototaxis response, but the nauplii produced by the broodstocks injected with dopamine $10^{-6}$ moll and control were weak. According to the egg classification by Primavera and Posadas (1981), the egg quality from the disqualified broodstock injected with $10^{-9}$ and $10^{-8}$ moll dopamine produced a good quality.

The diameter of eggs from the disqualified broodstock already injected with dopamine $10^{-9}, 10^{-8}, 10^{-7}, 10^{-6}$ moll and control were $0.29 ; 0.29 ; 0.29 ; 0.27$; and $0.27 \mathrm{~mm}$, respectively. It means that dopamine injection did not influence the egg diameter.

\section{CONCLUSIONS}

Dopamine can lengthen the time of egg maturation from the disqualified broodstock. The optimal dosage of $10^{-9}$ moll dopamine can be used to improve the quality of the disqualified tiger prawn broodstocks (three times breeding).

\section{ACKNOWLEDGMENTS}

I would like to thank SEARCA for funding this research. 


\section{REFERENCES}

Primavera J.H. 1983. Broodstock of Sugfo, Penaeus monodon Fab. SEAFDEC Extention Manual No.5. p.67.

Primavera J.H. and R.A. Posadas. 1981. Studies on eggs quality of the Penaeus monodon Fab. based on morphology and hatching rate. Aquaculture, 22: 269-277.

Riani E., Hitam M.S. and M. Eidman. 1995. Pengaruh pemberian berbagai dosis prostaglandin F-2 pada berbagai tempat penyuntikan terhadap ovulasi Udang Windu (Penaeus monodon Fab.) afkir. Jurnal Ilmu-ilmu Perairan dan Perikanan Indonesia. Jurusan MSP Faperikan IPB Bogor. Vol.III No.1.

Riani E., Hitam M.S. and M. Eidman. 1995. Pengaruh dosis dan waktu penyuntikan prostaglandin F-2 pada berbagai tempat penyuntikan terhadap ovulasi Udang Windu (Penaeus monodon Fab.) afkir. Jurnal Ilmuilmu Perairan dan Perikanan Indonesia. Jurusan MSP Faperikan IPB Bogor. Vol. III No.2.

Sarojini R., Nagabhushanan R. and M. Fingerman. 1995. In Vivo of dopamine and dopaminergic antagonists on testicular maturation in the Red Swamp Crayfish, Procambarus clarkii. Biology Bulletin, 189: 340-346.

Tseng W. 1987. Shrimp Mariculture. A Practical Manual. Department of Fisheries. University of Papua New Guinea, Port Moresby. p.305. 